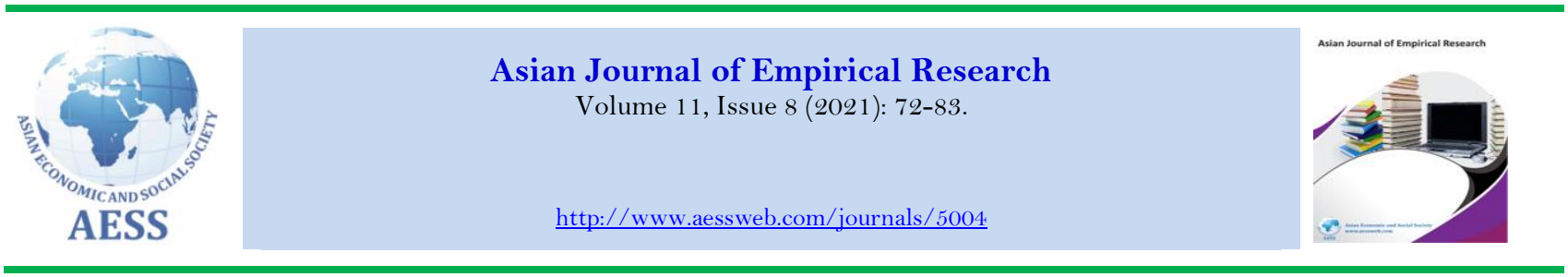

\title{
LONG-RUN AND SHORT-RUN EFFECTS OF TRADE OPENNESS ON LIFE QUALITY IN SUB-SAHARAN AFRICA
}

\author{
Guivis Zeufack Nkemgha \\ Aimée Viviane Mbita ${ }^{b}$ \\ Symphorin Engone Mve $^{b}$ \\ Rodrigue Tchoffo ${ }^{c}$
}

\begin{tabular}{l}
\hline Article History \\
\hline Received: 6 September 2021 \\
Revised: 18 October 2021 \\
Accepted: 8 November 2021 \\
Published: 29 November 2021
\end{tabular}

\section{Keywords}

Trade openness

Life quality

Former French colonies

Former British colonies.
${ }^{a}$ University of Bamenda, Cameroon.
${ }^{b}$ University of Omar Bongo, Gabon.
${ }^{C}$ University of Dschang, Cameroon.

ه nkemghazeufackguivis@yahoo.fr (Corresponding author)

Contribution/Originality: This paper contributes to the existing literature by investigating the neglected effects of trade openness on life quality. Moreover, the empirical evidence is based on the panels differentiated by their colonial origin.

DOI: $10.18488 /$ journal.1007.2021.118.72.83

$\operatorname{ISSN}(\mathrm{P}):$ 2306-983X/ISSN(E): 2224-4425

How to cite: Guivis Zeufack Nkemgha --- Aimée Viviane Mbita --- Symphorin Engone Mve --- Rodrigue Tchoffo (2021) Long-Run and Short-Run Effects of Trade Openness on Life Quality in Sub-Saharan Africa. Asian Journal of Empirical Research, 11(8), 72-83. 10.18488/journal.1007.2021.118.72.83

(C) 2021 Asian Economic and Social Society. All rights reserved.

\section{INTRODUCTION}

By opening its borders to international trade, a country allows its consumers to access foreign goods whose characteristics (quality, design, performance, etc.) are often different from locally produced goods. Thus, international trade allows a wider choice of products. This is explained by the taste for the variety of consumers: they want to have the choice between several types of goods and services for a given price range. Each consumer can then value a particular variety of a product: he wants to consume his "ideal product". Some will prefer the design of goods, others will prefer the comfort of the latter. Thus, international trade increases the well-being felt by consumers. This advantage of international trade is an argument for free trade. It is less often advanced, because the debate usually focuses on the gains in terms of growth that can be gained from international trade. However, the diversity of consumer goods is also a form of wealth, and one would surely suffer from losing it if the economy were brutally closed to world trade.

International exchange allows for economies of scale and therefore production at lower cost. With this in mind, international trade still makes it possible to increase factor productivity especially that of the capital factor, not 
through the specialization of economies, but through industrial concentration. Free trade allows companies to sell more, and therefore produce more and benefit from economies of scale. The opening of borders to international trade allows companies to find new customers in foreign markets. If so, companies to sell more, will also have to produce more. This increase in production leads, in many sectors and in particular the industrial sectors, the realization of economies of scale and thus lower production costs. Lower prices due to economies of scale increase consumers' purchasing power, which again increases the size of markets. Reducing production costs in companies through economies of scale allows lower selling prices for goods and services. The purchasing power of consumers is increasing, and they can buy more goods and services (the same or new products). This increased demand requires an increase in supply, i.e. production, which further enhances economies of scale and the possible decline in production prices. So, we have a "virtuous circle" between international trade and economic growth.

For many years, several economists have demonstrated that international trade has a positive impact on economic growth. Moreover, the evolution of many countries through international trade has enriched their population and improved their living conditions. These include some Asian countries such as Japan, Hong Kong, South Korea and Singapore whose development strategies were based on openness to global trade. Thus, international trade would be favorable for development.

According to UNITAD (2015) world trade in goods and services has progressed impressively, from US $\$ 5000$ billion in 1994 to nearly US $\$ 24$ billion in 2014. Thus, the increase in global trade has benefited all countries and has opened up extraordinary development opportunities for many of them. In addition, World Bank statistics show that the opening of the SSA region increased by $14.2 \%$ from 1990 to 2015 . Three factors contributed to this growth: the reduction of tariff and non-tariff barriers to international trade, the reduction of barriers to foreign direct investment and the progress made in the information and communication technology sector.

According to the World Trade Organization (2013) trade is an instrument of development and one of its mandates is to promote the quality of life of the population. However, despite enormous progress made by the MDGs, in 2015 , nearly 347 million poor people still suffer from hunger and lack access to basic services in SSA compared with 284 million in 1990 in the same region ${ }^{1}$. Thus, Sub-Saharan Africa is the region of the world where extreme poverty is more prevalent in terms of its level of development measured by the human development index (HDI). In UNDP (2014) report showed that the Human Development Index for Sub-Saharan Africa was 0.518. This index is low because it is below the world average of around 0.7 .

Empirically, several authors have investigated the effect of trade openness on quality of life. For some (Dollar \& Kraay, 2001; Gbetnkom, 1999; Jouini, 2015; Maëlan \& Raju, 2014; Winters, 2000) trade openness favors the quality of life of the populations. For others (Andoni \& Barusman, 2017; Barro, 2000; Emini, Kamgnia, \& Nembot, 2010) trade openness is a factor in the deterioration of life quality. However, none of these authors have thought of linking the relationship between trade openness and quality of life to decolonization.

If it has been established that trade openness has a significant impact on growth and quality of life, what about the countries of Sub-Saharan Africa? Can we say that the colonial past influences the relationship between trade openness and human development in sub-Saharan Africa?

Thus, the objective of this work is to evaluate and compare the contribution of trade openness to the human development of the former French colonies (FFC) and to that of the former British colonies (FBC) of SSA.

Indeed, Great Britain and French have adopted antagonistic decolonization processes in SSA. The first is credited with a decolonization fully assumed, negotiated and peaceful, while the second would be attributed a much more reluctant and conflicting decolonization. In addition, French, seeing its interests threatened, has granted independence to its African territories but with a hand on the economy including the operation account; which is not the case for the former British colonies.

The rest of the writing will be in the order of the following points: The next section presents some stylized facts about trade and quality of life in the two groups of countries in SSA, following by the literature review in section 3. Section 4 declines the adopted data and econometric issues. Results come at section 5 and we end at section 6 by the conclusion.

\section{STYLIZED FACTS}

Figures 1 \& 6 represent the average evolution of the main variables of the study not only for each country but also for each group of SSA countries during the period 2000-2016. 


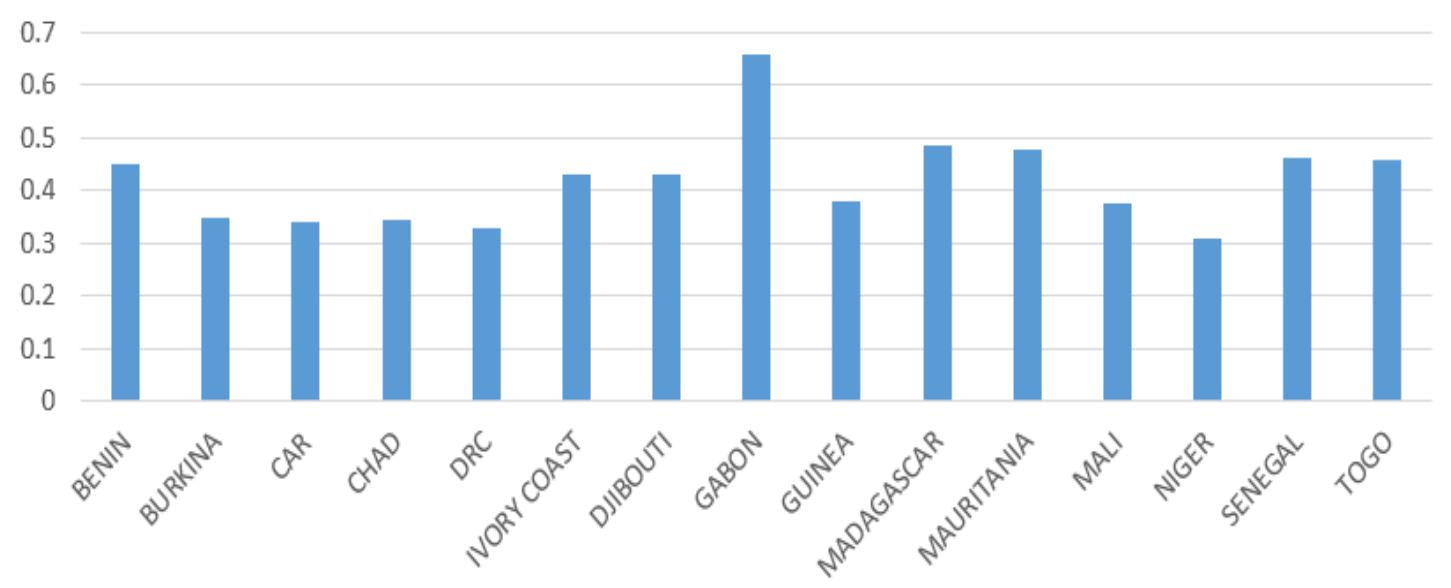

Figure-1. HDI in the FFC.

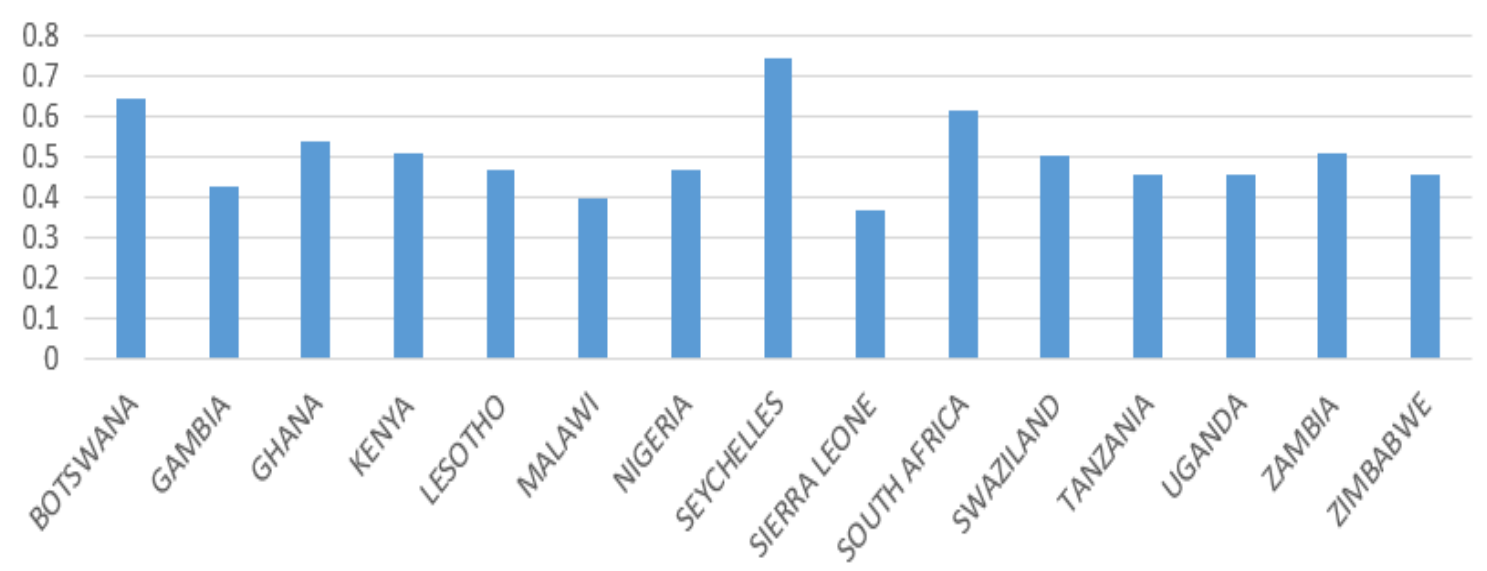

Figure-2. HDI in the FBC.

The observation of the average HDI in the former French colonies of Africa that belong to the franc zone shows that only Gabon recorded an average HDI greater than 0.5 during the period 2000-2016. Unlike the former French colonies of SSA, the evolution of the average HDI in the former British colonies of SSA shows that seven countries (Botswana, Ghana, Kenya, Seychelles, South Africa, Swaziland and Zambia) individually recorded an average HDI of more than 0.5 during the period 2000-2016, while the eight other former British colonies individually recorded an average of less than 0.5 during the same period. This illustration amply demonstrates that the former French and British colonies in SSA still have some way to go in improving the quality of life of their populations. But the fact remains that the former British colonies in SSA have recorded notable advances in human development compared to the former French colonies of SSA as shown in Figure 3.

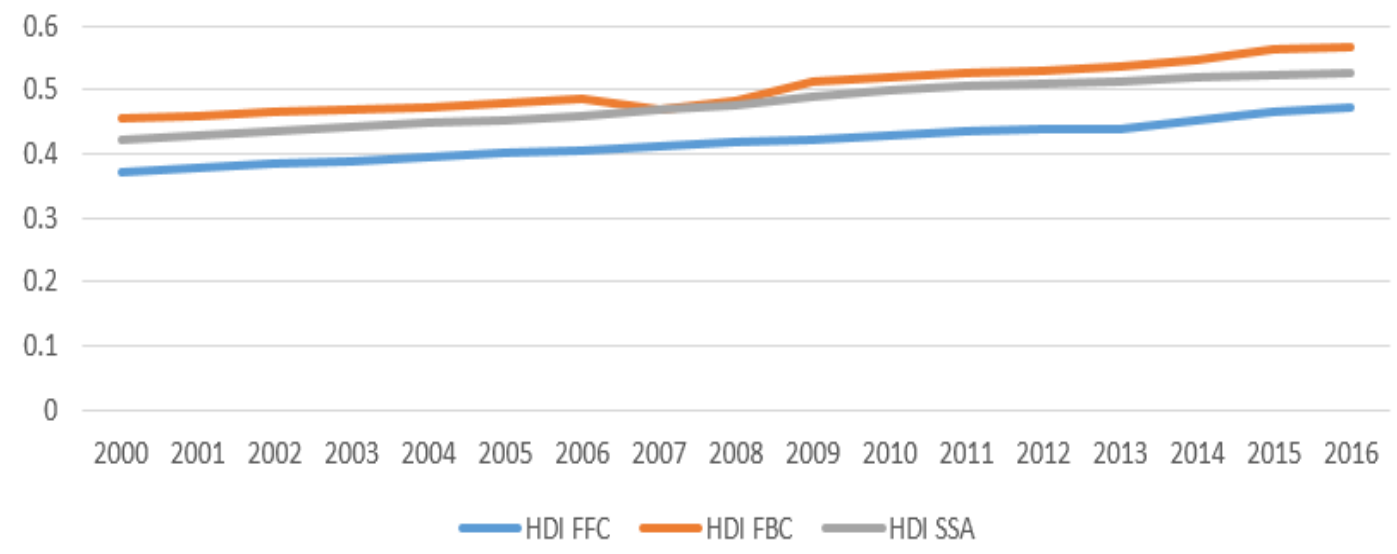

Figure-3. Comparative evolution of the average HDI in FFC, FBC and SSA. 


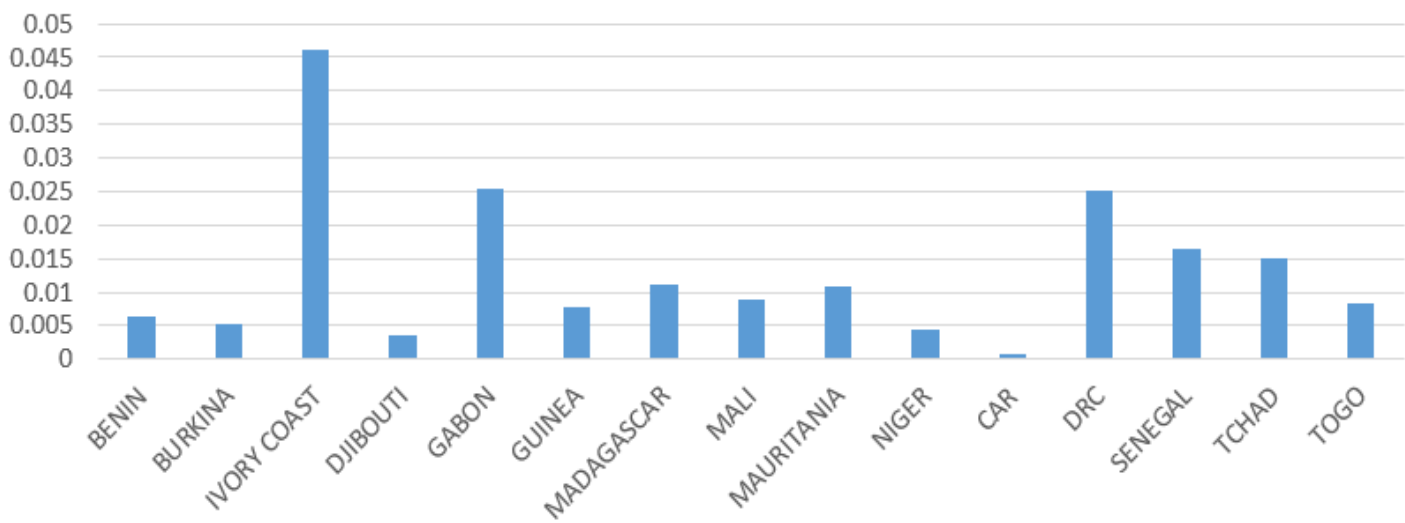

Figure-4. Trade in the FFC.

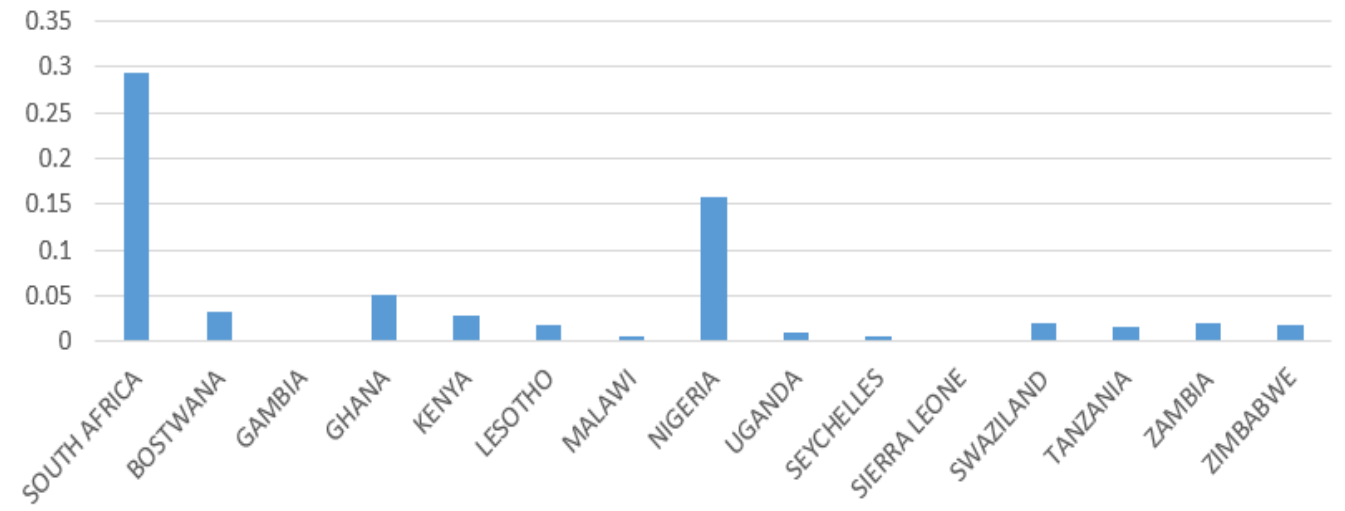

Figure-5. Trade in the FBC

The evolution of trade openness (measured by Squalli and Wilson (2011)) in the former French colonies of Africa shows that only the Ivory Coast recorded an average opening rate higher than 0.03 during the period $2000-2016$. Unlike the former French colonies in SSA, the evolution of the average opening rate in the former British colonies in SSA shows that four countries (South Africa, Botswana, Ghana and Nigeria) have recorded individually an average opening rate greater than 0.03 during the period 2000-2016, while the other eleven countries recorded an average opening rate of less than 0.03 during the same period. Overall, the evolution of the average opening rate during the period 2000-2016 in the former British colonies of SSA is greater than that recorded in the former French colonies of SSA during the same period as shown in Figure 6.

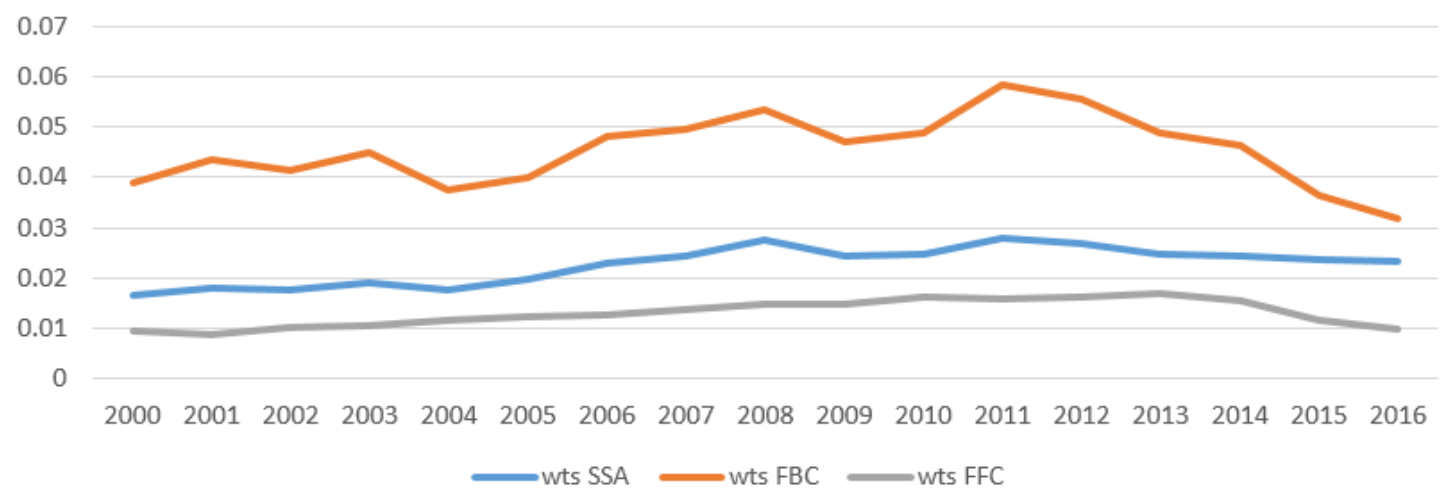

Figure-6. Comparative evolution of average opening index in FFC, FBC and SSA during the period 2000-2016.

It is in general observed that the average index of opening in SSA remains weak over the period 2000-2016. This situation can be explained by the fact that SSA countries have an economic structure based on commodities whose prices have been very volatile on the international market in recent years. Added to this is the problem of the isolation of some SSA countries. For among the fifteen countries that constitute a sample of former French colonies in Africa, $33.33 \%^{2}$ of these countries represent landlocked countries ${ }^{3}$ while $46.66 \%{ }^{4}$ of the fifteen countries that

${ }^{2}$ Among the fifteen countries that make up the sample of former French colonies in SSA, five of these countries are landlocked, namely Burkina Faso, CAR, Chad, Mal and Niger.

${ }^{3}$ A landlocked country is a country that is not open to the sea. 
make up the sample of former British colonies in SSA are landlocked countries; which does not facilitate their access to major markets (European market, Asian market and American market). In addition, isolation creates additional costs related to import and export in these countries. Hence, the problem of the operating account may also be one of the factors that contributes to explain the lower level of trade openness, particularly in the former French colonies of Africa. Despite a high rate of land lockedness, the former British colonies in SSA have achieved an average opening rate higher than that recorded in SSA in general and in the former French colonies of SSA, particularly during the period 2000-2016.

\section{LITERATURE REVIEW}

Economic theory has traditionally viewed trade openness as the result of a process to reduce barriers to trade in goods and services. While the removal of trade barriers is the most direct solution of free trade, many countries have opted for more progressive and flexible approaches. David Ricardo's theory of competitive advantage is at the heart of the expected efficiency of global trade openness. One of the enduring legacies of the new theory of growth is the emphasis on the role of trade and foreign direct investment as the main drivers of economic growth. Neo-liberals have argued that trade liberalization has the potential to promote competition at local and global levels. This argument is based on the fact that in attempting to enter the foreign market or compete with foreign firms, domestic exporting firms must eliminate inefficiency and produce high quality goods at low cost. They can only do this through the acquisition of new and modern technologies that will make them competitive on the international market (Thirlwall, 2000). McCulloch, Winters, and Cirera (2001) argue that the effect of trade openness on quality of life depends on the specificities of each country. These channels can be positive or negative. The first configuration is generally in developed countries, better equipped to cope with external technological shocks, and the second occurs in poor countries that do not yet use modern production techniques efficiently. This literature revolves around the authors who worked on some countries having the status of either former French colony or former British colony of Sub-Saharan Africa. Gbetnkom (1999); Emini et al. (2010) and Keho (2017) are some authors who have evaluated the effect of trade openness on the quality of life of countries having the status of former French colonies of SSA.

Gbetnkom (1999) examined the impact of openness policy on poverty in Cameroon. Analyzes show that liberalization has a positive effect on agriculture, trade performance, investment and the social sectors that are the ingredients of the economic growth needed for the fight against poverty. Emini et al. (2010) assessed the impact of unilateral and total liberalization of foreign trade on poverty in Cameroon. Using the computable general equilibrium approach with micro-simulation and considering VAT (value-added tax) as a compensatory device for the shortfall in customs revenue, they show that the liberalization scenario considered would result in an increase net of the number of poor in the order of $5 \%$ of the national population; an increase of $12 \%$ of the population of poor at the national level. For these authors, although this worsening of poverty is widespread, it would increase the absolute contribution of the rural area to poverty. Keho (2017) analyzed the impact of trade openness on economic growth in Ivory Coast. He uses Autoregressive Distributive Lags method on data from 1965 to 2014 and finds that trade openness has a positive and significant effect on economic growth both in the short and the long run. Nwafo, Adenikinju, and Ogujiuba (2007); Sakyi (2011); Henry and Philip (2014); Musila and Yiheyis (2015) and Hlalefang and Chitauro (2018) are some authors who have evaluated the effect of trade openness on the quality of life of countries having the status of former British colonies of SSA. Nwafo et al. (2007) examined the effect of trade liberalization on poverty in Nigeria. Using a dynamic equilibrium model, their results showed that liberalization had positive consequences for urban households and negative consequences for rural households whose income depended on land and labor. Sakyi (2011) uses the Autoregressive Distributive Lags test (ARDL) to determine the extent to which trade openness and inflows of foreign aid have an impact on economic growth in Ghana, after liberalization. He finds that this effect is positive and statistically significant both in the short and the long-run. Henry and Philip (2014) analyzed the impact of trade liberalization on the well-being of Nigerian populations. By performing macromicro simulations on a general equilibrium model, they found a positive impact of trade liberalization on the consumption of goods and services as well as on real household income. Musila and Yiheyis (2015) analyzed the effect of trade openness on Kenya's level of investment and economic growth rate using annual time series data. They evaluate the global trade openness and openness induced by trade policy. By controlling a number of factors, they show that overall trade openness has been found to have a positive impact on the level of investment and the rate of economic growth, although the effect on the latter is statistically insignificant. In contrast, the authors found that the openness induced by trade policy had a significant negative impact on investment and the rate of economic growth. Hlalefang and Chitauro (2018) analyze the effects of trade liberalization on Swaziland's economic growth using annual data from 1990 to 2014. To do this, the study incorporated foreign direct investment (FDI) and employment (EMP) as an additional variable to the multivariate framework.

The Autoregressive Distributive Lags test (ARDL) was used to test the existence of a long-term relationship between the variables. Empirical results have shown that trade openness has a significant positive effect on economic growth in Swaziland. However, the results of these studies do not allow us to say whether the colonial origin has influenced the relationship between trade openness and quality of life.

Moreover, based on existing empirical work, we find that several authors have examined the effect of trade openness on quality of life. Some have captured (or measured) quality of life through economic growth (Sachs \& Warner, 1995) real income (Henry \& Philip, 2014) poverty (Gbetnkom, 1999) and inequality (Andoni \& Barusman,

${ }^{4}$ Among the 15 countries that make up the sample of former British colonies in SSA, seven of these countries are landlocked, namely Botswana, Lesotho, Malawi, Swaziland, Uganda, Zambia and Zimbabwe. 
2017). All these authors did not use the Human Development Index as an indicator of the quality of life in their work. Yet, the HDI is an internationally recognized index of quality of life that is even used to rank the countries of the world in terms of human development every year. The Human Development Index (HDI) and the opening index of Squalli and Wilson (2011) were used in this work to measure respectively the Human Development and the openness of a country. For this purpose, a macroeconomic approach is used with a sample made up of Sub-Saharan Africa countries. This sample is subdivided into two subsamples, namely: the sample of former French colonies and that of former British colonies in SSA.

\section{DATA AND ECONOMETRIC ISSUES}

This section will discuss about the sample and variables that will be used in the analysis. Then, it will be followed by further reasoning about why adding each variable into the regression and the source of the data. This section also provides justifications for the estimation technique to be used.

\subsection{Data}

To empirically test the relationship between trade openness and quality of life, panel data from SSA countries from 2000 to 2016 were used. In this work, the SSA sample is subdivided into two samples: the sample of the former French colonies and that of the former British colonies as shown in Appendices (Tables A1 and A2).

The dependent variable of our econometric model is Human Development Index. Its measures the level of development of the world countries. This index takes into consideration four indicators within three dimensions (health, education and income per capita).

Our main independent variable is trade openness. It is measured from the opening index of Squalli and Wilson (2011)

given by: wts $=\frac{(x+m) i}{\sum_{j=1}^{n}(\mathrm{x}+\mathrm{m}) \mathrm{j}} \times \frac{(x+m) i}{G D P i}$, Where $x, m, G D P i$ and $j$ respectively represent exports, imports, gross domestic product of country $\mathrm{i}$ and all participants in world trade. According to McCulloch et al. (2001) international trade influences economic growth and well-being. The abbreviation as well as a measure and source for each variable are giving in appendices (cf. Table A3). The descriptive statistics and the correlation matrices between the variables of the different samples are summarized in Tables 1,2, 3 and 4 below.

Table-1. Descriptive statistics on the sample of former French colonies in Africa.

\begin{tabular}{c|c|c|c|c|c|c}
\hline & HDI & WTS & OPEN & FDI & INF & EXDI \\
\hline Mean & 0.417953 & 0.013031 & 72.08916 & 4.513106 & 16.00213 & 0.771 \\
\hline Median & 0.412000 & 0.009231 & 70.61000 & 2.936431 & 2.855534 & 0.791 \\
\hline Maximum & 0.700000 & 0.063590 & 175.0000 & 46.49370 & 2630.123 & 0.09 \\
\hline Minimum & 0.262000 & 0.000454 & 11.09700 & -14.77872 & -8.974740 & 0.309 \\
\hline Std. Dev. & 0.091679 & 0.012642 & 25.82311 & 6.413061 & 164.6061 & 0.9 \\
\hline Observations & 255 & 255 & 255 & 255 & 255 & 255 \\
\hline
\end{tabular}

Table-2. Descriptive statistics on the sample of former British colonies in Africa.

\begin{tabular}{c|c|c|c|c|c|c}
\hline & HDI & WTS & OPEN & FDI & INF & EXDI \\
\hline Mean & 0.501941 & 0.045266 & 83.91263 & 4.634779 & 9.612125 & 0.735 \\
\hline Median & 0.484000 & 0.016372 & 67.08000 & 3.501834 & 7.379439 & 0.768 \\
\hline Maximum & 0.782000 & 0.387392 & 217.3047 & 54.06343 & 74.29818 & 0.138 \\
\hline Minimum & 0.180000 & 0.000821 & 20.72000 & -3.284940 & -9.616154 & 0.215 \\
\hline Std. Dev. & 0.108152 & 0.078823 & 45.22669 & 5.382837 & 8.869024 & 0.959 \\
\hline Observations & 255 & 255 & 255 & 255 & 255 & 255 \\
\hline
\end{tabular}

Table-3. Matrix of correlation of variables in the sample of former French colonies in Africa.

\begin{tabular}{c|c|c|c|c|c|c}
\hline & HDI & WTS & OPEN & FDI & INF & EXDI \\
\hline IDH & 1.000000 & & & & & \\
\hline WTS & 0.287605 & 1.000000 & & & & \\
\hline OPEN & 0.454167 & 0.332215 & 1.000000 & & & \\
\hline FDI & -0.008645 & -0.048254 & 0.343672 & 1.000000 & & \\
\hline INF & -0.110944 & -0.026852 & -0.117532 & -0.038249 & 1.000000 & \\
\hline EXDI & -0.0647 & -0.2487 & -0.2984 & 0.1292 & 0.0347 & 1.000000 \\
\hline
\end{tabular}


Table-4. Matrix of correlation of variables in the sample of former British colonies in Africa.

\begin{tabular}{c|c|c|c|c|c|c}
\hline & HDI & WTS & OPEN & FDI & INF & EXDI \\
\hline HDI & 1.000000 & & & & & \\
\hline WTS & 0.241151 & 1.000000 & & & & \\
\hline OPEN & 0.433768 & -0.168284 & 1.000000 & & & \\
\hline FDI & 0.195448 & -0.193344 & 0.335846 & 1.000000 & & \\
\hline INF & -0.144778 & -0.060019 & -0.038212 & 0.040424 & 1.000000 & \\
\hline EXDI & 0.0126 & -0.4905 & 0.2509 & 0.1084 & 0.0221 & 1.000000 \\
\hline
\end{tabular}

Tables 3 and 4 show a positive correlation between the two indicators of trade openness and quality of life. This correlation is confirmed by the slopes of Figures 7 and 8.

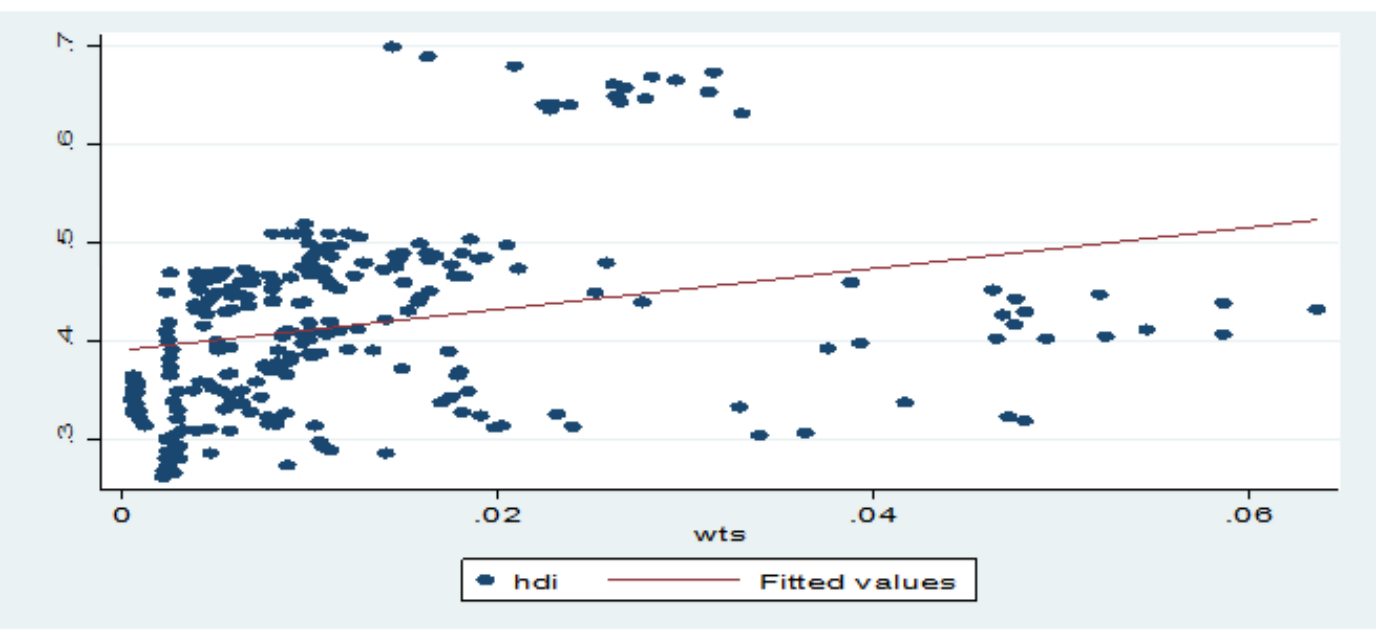

Figure-7. Trade openness and life quality in FFC.

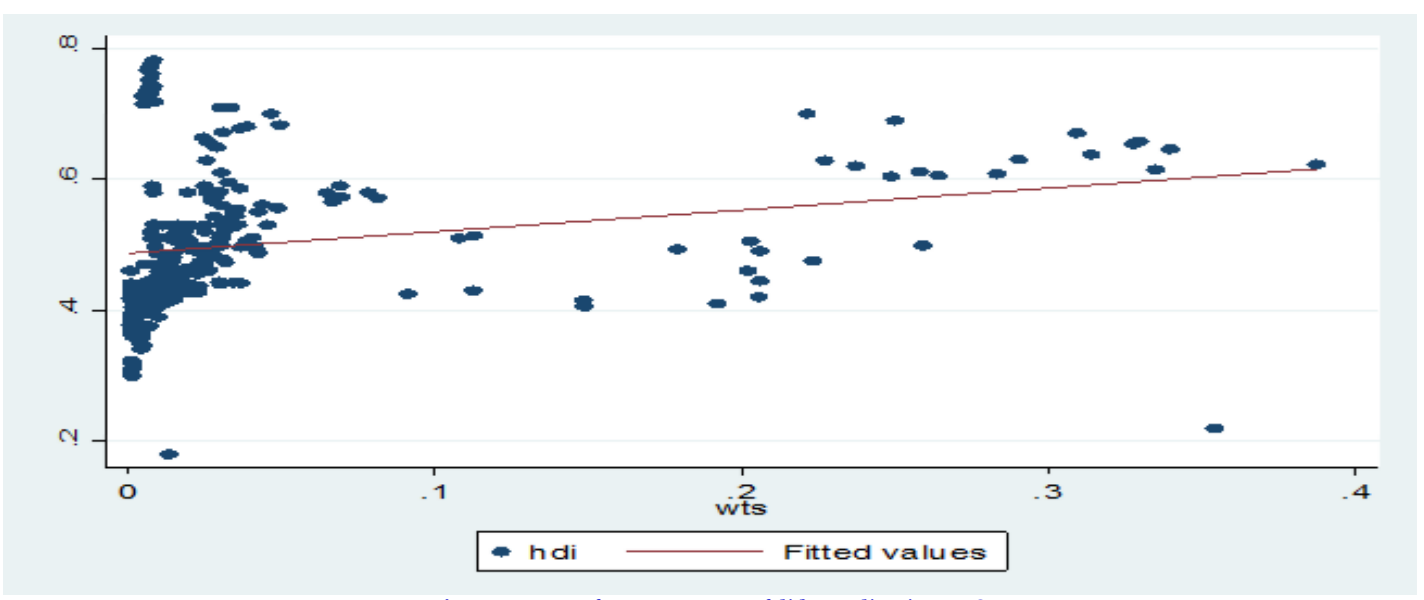

Figure-8. Trade openness and life quality in FBC.

\subsection{Econometric Issues}

To analyze the effect of trade openness on human development, this study uses the neoclassical augmented growth model developed by Mankiw, Romer, and Weil (1992). Taking into account the variable of interest (trade openness) and the heterogeneity of the coefficients and other control variables, the model can be expressed as follows:

$$
Y_{i t}=\alpha_{i}+\lambda_{i} Y_{i t-1}+\sum_{p=1}^{k} \beta_{p i} X_{i t}^{p}+\gamma_{1 i} w t s+\varepsilon_{i t}
$$

Where $Y_{i t}$ is HDI for country $i$ at time $t, X$ is the vector of control variables, including Foreign Direct Investment (FDI), inflation (INF) and export diversification index (EXDI). $\varepsilon_{i t}$ is an error term, and $\alpha_{i}$ reflects country-specific effects. The transformation of Eq. 1 as an error correction gives:

$$
\Delta Y_{i t}=\varphi_{i}\left(Y_{i t}-\theta_{0 i}-\sum_{p=1}^{k} \theta_{p i} X_{i t-1}^{p}-\delta_{1 i} w t s_{i t-1}\right)-\sum_{p=1}^{k} \beta_{p i} \Delta X_{i t}^{p}-\gamma_{1 i}-\Delta w t s_{i t}+\varepsilon_{i t}
$$

With $\theta_{0 i}=\frac{\alpha_{i}}{1-\lambda_{i}}, \theta_{p i}=\frac{\beta_{p i}}{1-\lambda_{i}}, \delta_{1 i}=\frac{\gamma_{1 i}}{1-\lambda_{i}}, \varphi_{i}=-\left(1-\lambda_{i}\right)$

Where $\theta_{0 i}$ is introduced for country-specific effects, $\varepsilon_{i t}$ represents the term of error, $\theta_{p i}$ and $\delta_{1 i}$ capture the dynamic of long-run effects, while $\beta_{p i}$ and $\gamma_{1 i}$ capture the short-run dynamics. Finally, $\varphi_{i}$ represents adjustment speed toward the long-run state; this should be negative and significant to confirm the long-run relationship between 
trade openness and human development. Following Pesaran, Shin, and Smith (1999) and Jouini (2015) the Pooled Mean Group (PMG) approach is used to estimate dynamic heterogeneous panels by considering long-run potential long-run linkage among variables. The PMG equilibrium relations, contrary to other techniques, such as the dynamic panel GMM method, that purge any estimation approach allows identical long-run coefficients without assuming homogeneous short-run parameters. By doing so, the PMG estimation approach differs from techniques, such as the Mean Group (MG) developed by Pesaran and Smith (1995) that estimate a regression for each group and then calculate the coefficient means (Evans, 1997; Lee, Pesaran, \& Smith, 1996). The MG long-run estimators are consistent, but they are inefficient if coefficient homogeneity holds. Under these conditions, the PMG estimation approach is useful since it provides consistent and efficient long-run estimators when parameter homogeneity holds. The PMG approach is preferable to the MG method since it provides estimates that are less sensitive to outlier estimates. We address endogeneity concerns by augmenting the PMG estimator with lags of regressors and dependent variables to minimize the resultant bias and ensure that the regression residuals are serially uncorrelated. Eq. 2 is rewritten as follows:

$$
\Delta Y_{i t}=\varphi_{i}\left(Y_{i t}-\theta_{0 i}-\sum_{p=1}^{k} \tilde{\theta}_{p i} X_{i t-1}^{p}-\tilde{\delta}_{1 i} w t s_{i t-1}\right)-\sum_{p=1}^{k} \beta_{p i} \Delta X_{i t}^{p}-\gamma_{1 i}-\Delta w t s_{i t}+\varepsilon_{i t}
$$

\section{RESULTS AND INTERPRETATIONS}

Before presenting the results of the quality of life model, we will first present the results of the preliminary tests (cross-dependence test, stationarity tests and cointegration test). These results are summarized in Table 5, 6 and 7 below. The use of the cross-dependency test of Pesaran (2004) reveals that all the variables of the FFC model admit a cross-dependence unlike the FBC model where the variables FDI and OPEN admit a cross-independence as shown in Table 5 .

Table-5. Cross-Dependence test of Pesaran (2004)

\begin{tabular}{c|c|c}
\hline \multirow{2}{*}{ Variables } & FFC & FBC \\
\cline { 2 - 3 } & P-value & P-value \\
\hline HDI & 0.00 & 0.00 \\
\hline WTS & 0.00 & 0.00 \\
\hline INF & 0.00 & 0.02 \\
\hline EXDI & 0.00 & 0.00 \\
\hline FDI & 0.00 & 0.275 \\
\hline OPEN & 0.00 & 0.386 \\
\hline
\end{tabular}

Since the variables FDI and OPEN admit transverse independence in the FBC sample, we will use for this purpose a first generation stationary test (Fisher test) to verify the existence or not of the unit root. For the rest (the variables which admit a transverse dependence), we will use the second stationary test like the test of Pesaran (2007). It emerges from the results of the stationary tests that three variables (WTS, INF and EXDI) are stationary at level in the FFC model against two variables (FDI and INF) in the FBC model as shown in Table 6. The rest of the variables of the two models being stationary in first difference.

Table-6. Results of stationary tests.

\begin{tabular}{c|c|c|c|c|c}
\hline \multirow{2}{*}{ Variables } & \multicolumn{3}{|c|}{ Pesaran test } & \multicolumn{2}{c}{ Fisher test } \\
\cline { 2 - 5 } & P-value at level & P-value at first difference & P-value at level & P-value at first difference \\
\hline & \multicolumn{2}{|c|}{ Stationary tests on variables that belong to the model of Former French Countries } \\
\hline HDI & 1.00 & 0.00 & - & - \\
\hline INTS & 0.00 & - & - & - \\
\hline FDI & 0.01 & - & - & - \\
\hline OPEN & 0.54 & 0.00 & - & - \\
\hline EXDI & 0.00 & - & - & - \\
\hline & 0.105 & Stationary tests on variables that belong to the model of former British countries & - \\
\hline HDI & 0.99 & 0.00 & - & - \\
\hline WTS & 0.18 & 0.00 & - & - \\
\hline INF & 0.00 & - & - & - \\
\hline FDI & - & - & 0.00 & - \\
\hline OPEN & - & - & 0.00 & - \\
\hline EXDI & 0.744 & - & - \\
\hline
\end{tabular}

Our variables being integrated with different orders, we will perform the Kao cointegration test to verify whether there is a long run relationship between the explanatory variables and the quality of life in the two models. The result of the cointegration test of Kao (1999) is given in Table 7. This table shows that the probability of each model are less than $5 \%$. This allows us to validate the existence of a cointegrating relationship between the explanatory variables and the quality of life in each model. 
Table-7. Results of Kao cointegration test.

\begin{tabular}{c|c|c}
\hline & ADF-statistic & P-value \\
\hline FFC model & 2.1263 & 0.0167 \\
\hline FBC model & 2.1600 & 0.0154 \\
\hline
\end{tabular}

The results of the stationary and cointegration tests allow us to use the Pooled Mean Group method to estimate the parameters of our growth model. Estimating the human development Equation by the Pooled Mean Group method shows that the speed of adjustment is negatively significant for both models, confirming the cointegration relationship between the variables and implying that the linkage between human development and explanatory variables is characterized by high predictability and that the spread movement is mean-reverting Table 8 . This result also shows that the trade openness variable measured by Squalli and Wilson (2011) has no effect on human development in the both groups of countries in the short run. However, it has a positive and significant effect on human development in the both group of countries in the long-run. Thus, an increase in trade openness of $1 \%$ will lead to an increase in human development of $2.9 \%$ and $9.5 \%$ respectively in FFCs and FBCs in the long-run. This situation can be explained by the fact that an opening favors exports and imports activities. This exchange with the rest of world allows a country to improve the health facility and the quality of education of their population. It also favors the arrival of foreign currency through the exportations of goods and services. These advantages will ultimately improve the human development of the population. This result is consistent with the work of Sachs and Warner (1995); Dollar and Kraay (2001) and Maëlan and Raju (2014). The contribution of trade openness to human development is 3.27 times higher in the former British colonies than that recorded in the former French colonies of SSA. The using of the rate of trade as a proxy of trade openness confirms the above results in the in both groups of countries in the long-run. Thus, an increase in trade openness of one unit will lead to an increase in human development of $0.0125 \%$ and $0.0649 \%$ respectively in FFCs and FBCs in the long-run. With a rate of trade, the contribution of trade openness on human development is 5.19 times higher in the former British colonies than that recorded in the former French colonies of SSA. We can see that, despite a high landlocked rate in the sample of former British colonies compared to that of the former French colonies of SSA, trade openness promotes more human development in the former British colonies than in the former French colonies of SSA.

Table-8. The effect of trade openness on human development.

\begin{tabular}{|c|c|c|}
\hline \multicolumn{3}{|c|}{ Trade openness is measure as Squalli and Wilson index (WTS) } \\
\hline Variables & Model 1 (FFC) & Model 2 (FBC) \\
\hline Long- run & HDI & HDI \\
\hline WTS & $\begin{array}{c}2.913608^{* * * *} \\
(0.00)\end{array}$ & $\begin{array}{c}9.504625^{* * * *} \\
(0.00)\end{array}$ \\
\hline FDI & $\begin{array}{c}0.000493 \\
(0.3)\end{array}$ & $\begin{array}{c}-0,002731^{* *} \\
(0.01)\end{array}$ \\
\hline INF & $\begin{array}{c}-0.001441 \\
(0.1)\end{array}$ & $\begin{array}{c}0.003563^{* * * *} \\
(0.00)\end{array}$ \\
\hline EXDI & $\begin{array}{c}0.647942^{* * * *} \\
(0.00)\end{array}$ & $\begin{array}{c}0.700352^{* * * *} \\
(0.00)\end{array}$ \\
\hline \multicolumn{3}{|l|}{ Short-run } \\
\hline CointeqO1 & $\begin{array}{c}-0.045141^{*} * \\
(0.04)\end{array}$ & $\begin{array}{c}-0.021934^{* * * *} \\
(0.00)\end{array}$ \\
\hline $\mathrm{D}(\mathrm{IDH}(-1))$ & $\begin{array}{c}-0.111394 \\
(0.7)\end{array}$ & - \\
\hline $\mathrm{D}(\mathrm{IDH}(-2))$ & $\begin{array}{c}-0.192580 \\
(0.2)\end{array}$ & - \\
\hline $\mathrm{D}(\mathrm{WTS})$ & $\begin{array}{c}0.820403 \\
(0.3)\end{array}$ & $\begin{array}{c}0.405004 \\
(0.2)\end{array}$ \\
\hline $\mathrm{D}(\mathrm{FDI})$ & $\begin{array}{c}0.000293 \\
(0.2)\end{array}$ & $\begin{array}{c}-0.000695 \\
(0.1)\end{array}$ \\
\hline $\mathrm{D}(\mathrm{INF})$ & $\begin{array}{c}0.000131 \\
(0.7)\end{array}$ & $\begin{array}{c}-0.000142 \\
(0.4)\end{array}$ \\
\hline $\mathrm{D}(\mathrm{EXDI})$ & $\begin{array}{c}0.010039 \\
(0.2)\end{array}$ & $\begin{array}{c}0.113077 \\
(0.1)\end{array}$ \\
\hline Observations & 210 & 240 \\
\hline
\end{tabular}




\begin{tabular}{|c|c|c|}
\hline \multicolumn{3}{|c|}{ Trade openness is measure as the rate of openness $(\mathrm{X}+\mathrm{M}) / \mathrm{GDP}$ : OPEN } \\
\hline Long-run & & \\
\hline OPEN & $\begin{array}{c}0.000125^{* * * *} \\
(0.00)\end{array}$ & $\begin{array}{c}0.000649^{* * * *} \\
(0.00)\end{array}$ \\
\hline FDI & $\begin{array}{c}-0.000176^{* * *} \\
(0.00)\end{array}$ & $\begin{array}{c}0.001373^{* *} \\
(0.03)\end{array}$ \\
\hline INF & $\begin{array}{c}0.000301^{* * *} * \\
(0.00)\end{array}$ & $\begin{array}{c}-0.000230 \\
(0.2)\end{array}$ \\
\hline EXDI & $\begin{array}{c}-0.023229 \\
(0.6)\end{array}$ & $\begin{array}{c}0.042335^{* *} \\
(0.01)\end{array}$ \\
\hline \multicolumn{3}{|l|}{ Short-run } \\
\hline Cointeq01 & $\begin{array}{c}-0.311514^{* *} \\
(0.04)\end{array}$ & $\begin{array}{c}-0.434068^{* * *} * \\
(0.00)\end{array}$ \\
\hline $\mathrm{D}(\mathrm{OPEN})$ & $\begin{array}{c}-0.000125^{* *} \\
(0.02)\end{array}$ & $\begin{array}{c}0.000132 \\
(0.5)\end{array}$ \\
\hline $\mathrm{D}(\mathrm{FDI})$ & $\begin{array}{c}0.0000747 \\
(0.8)\end{array}$ & $\begin{array}{c}-0.001163 \\
(0.4)\end{array}$ \\
\hline $\mathrm{D}(\mathrm{INF})$ & $\begin{array}{c}0.000166^{* *} \\
(0.03)\end{array}$ & $\begin{array}{c}-0.001050 \\
(0.5)\end{array}$ \\
\hline $\mathrm{D}(\mathrm{IDEX})$ & $\begin{array}{c}0.018605 \\
(0.1)\end{array}$ & $\begin{array}{l}0.193124 \\
(0.3)\end{array}$ \\
\hline $\mathrm{C}$ & $\begin{array}{c}0.112793^{* *} \\
(0.02)\end{array}$ & $\begin{array}{c}0.148853^{* * * *} \\
(0.00)\end{array}$ \\
\hline (a)TREND & $\begin{array}{c}0.001828^{* *} \\
(0.04)\end{array}$ & $\begin{array}{c}0.004224^{* * * *} \\
(0.00)\end{array}$ \\
\hline Observations & 240 & 240 \\
\hline
\end{tabular}

Note: **, *** mean significant at 5 and $1 \%$. Values in parentheses represent Student's statistics.

\section{CONCLUSION}

While the development benefit of trade openness has been largely recognized, the studies analyzing the effect of trade openness on life quality is limited. Better understanding the potential effect of trade openness on life quality is important given the evidence on the growth - enhancing and poverty - reducing effects of life quality. To fill the gap, this paper assesses and compare the long - run and short - run effects of trade openness on life quality in subSaharan African countries during the period 2000-2016. We used two trade openness indicators, namely: Squalli and Wilson index (WTS) and the rate of trade (OPEN). Our study departs from other studies by using the human development index as a proxy for quality of life and by differentiating countries according to their colonial origin.

On this basis the following findings are established. The trade openness variable measured by Squalli and Wilson index has no effect on human development in the both groups of countries in the short-run. However, it has a positive and significant effect on human development in the both group of countries in the long-run. The contribution of trade openness to human development is 3.27 times higher in the former British colonies than that recorded in the former French colonies of SSA. The using of the rate of trade as a proxy of trade openness confirms the above results in the in both groups of countries in the long-run. With a rate of trade, the contribution of trade openness to human development is 5.19 times higher in the former British colonies than that recorded in the former French colonies of SSA.

Therefore, a policy implication resulting from the empirical analysis is that sub-Saharan countries should change their current production structure (based on natural resources and agricultural products whose prices on international markets are volatile) to migrate to processing economies that would further promote human development. Furthermore, the former French colonies of Sub-Saharan Africa must particularly renegotiate their trade and monetary agreements with France in order to boost their trade.

Funding: This study received no specific financial support.

Competing Interests: The authors declare that they have no competing interests.

Acknowledgment: All authors contributed equally to the conception and design of the study.

Views and opinions expressed in this study are the authors' views and opinions; the Asian

Journal of Empirical Research shall not be responsible or answerable for any loss, damage, or liability, etc. caused in relation to/arising out of the use of the content. 


\section{REFERENCES}

Andoni, B. F., \& Barusman, M. Y. S. (2017). The impact of international trade on income inequality in the United States since 1970's. European Research Studies, 20(4A), 35-50. Available at: https://doi.org/10.35808/ersj/818.

Barro, R. J. (2000). Inequality and growth in a panel of countries. Journal of Economic Growth, 5(1), 5-32.

Dollar, D., \& Kraay, A. (2001). Trade growth and poverty. Working Paper $\mathrm{n}^{\circ} 2615$. Department of Research Policy, World Bank, Washington.

Emini, C. A., Kamgnia, D. B., \& Nembot, N. L. (2010). Trade liberalization and poverty in Africa: The case of Cameroon (pp. 125173). Ottawa, Canada: University Presses of Laval, Quebec, Canada and International Development Research Center (IDRC).

Evans, P. (1997). How fast do economics converge? Review of Economics and Statistics, 79(2), 219-225. Available at: https://doi.org/10.1162/003465397556809.

Gbetnkom, D. (1999). Trade liberalization and poverty in Sub-Saharan Africa: An examination of the case of Cameroon. African Review of Economics and Management, 1(2), 107-135.

Henry, O., \& Philip, O. A. (2014). Household welfare impact of trade liberalization in Nigeria: A computable general equilibrium model. Journal of Economic and Sustainable Development, 5(28), 41-53.

Hlalefang, K., \& Chitauro, M. (2018). The impact of trade liberalisation on economic growth in Switzerland. MPRA Paper 89884, University Library of Munich, Germany.

Jouini, J. (2015). Linkage between international trade and economic growth in GCC countries: Empirical evidence from PMG estimation approach. The Journal of International trade E Economic Development, 24(3), 341-372. Available at: https://doi.org/10.1080/09638199.2014.904394.

Kao, C. (1999). Spurious regression and residual-based tests for cointegration in panel data. Journal of Econometrics, 90(1), 1-44. Available at: https://doi.org/10.1016/s0304-4076(98)00023-2.

Keho, Y. (2017). The impact of trade openness on economic growth: The case of Ivory Coast. Cogent Economics E Finance, 5(1), 114.

Lee, K., Pesaran, M. H., \& Smith, R. (1996). Growth and convergence in a multi-country empirical stochastic Solow model. Journal of Applied Economics, 12(4), 357-392. Available at: https://doi.org/10.1002/(sici)1099-1255(199707)12:4\%3C357::aidjae441\%3E3.0.co;2-t.

Maëlan, L., \& Raju, J. (2014). Does trade reduce poverty? A view from Africa. Journal of African Trade, 1(1), 5-14. Available at: https://doi.org/10.1016/j.joat.2014.06.001.

Mankiw, N. G., Romer, D., \& Weil, D. N. (1992). A contribution to the empirics of economic growth. The Quarterly Journal of Economics, 107(2), 407-437.

McCulloch, N., Winters, L. A., \& Cirera, X. (2001). Trade liberalization and poverty: A handbook: Centre for Economic Policy Research. UK: British Library Cataloguing.

Musila, J. W., \& Yiheyis, Z. (2015). The impact of trade openness on growth: The case of Kenya. Journal of Policy Modeling, 37(2), 342-354. Available at: https://doi.org/10.1016/j.jpolmod.2014.12.001.

Nwafo, M., Adenikinju, A., \& Ogujiuba, K. (2007). The impacts of trade liberalization on poverty in Nigeria: Dynamic simulations in a CGE model. Working Papers No. MPIA 2007-16, PEP-MPIA.

Pesaran, M. H., Shin, Y., \& Smith, R. P. (1999). Pooled mean group estimation of dynamic heterogeneous panels. Journal of the American Statistical Association, 94(446), 62 1-634. Available at: https://doi.org/10.1080/01621459.1999.10474156.

Pesaran, M. H., \& Smith, R. (1995). Estimating long-run relationships from dynamic heterogeneous panels. Journal of Econometrics, 68(1), 79-1 13. Available at: https://doi.org/10.1016/0304-4076(94)01644-f.

Pesaran, M. H. (2004). General diagnostic tests for cross section dependence in panels. University of Cambridge, Faculty of Economics, Cambridge Working Papers in Economics No. 0435.

Pesaran, M. H. (2007). A simple panel unit root test in the presence of cross section dependence. Journal of Applied Economics, 22(2), 265-312.

Sachs, J., \& Warner, A. (1995). Economic reform and the process of economic integration. Brookings Papers of Economic Activity, 1995(1), 1-95. Available at: https://doi.org/10.2307/2534573.

Sakyi, D. (2011). Trade openness, foreign aid and economic growth in post-liberalisation Ghana: An application of ARDL bounds test. Journal of Economics and International Finance, 3(3), 146-156.

Squalli, J., \& Wilson, K. (2011). A new measure of trade openness. The World Economic, 34(10), 1745-1770. Available at: https://doi.org/10.1111/j.1467-9701.2011.01404.x.

Thirlwall, A. P. (2000). Trade liberalization and economic growth: Theory and evidence. African Development Bank Economic Research Paper No. 63.

UNDP. (2014). Human development report. Retrieved from: http://hdr.undp.org/en/2014-report

UNITAD. (2015). Delivering on a sustainable agenda. Annual Report 2015.

Winters, L. A. (2000). Trade policy and poverty: What are the links? CEPR Discussion Paper No. 2382, London.

World Trade Organization. (2013). The Bali ministerial declaration,2013WT/MIN(13)/DEC/W/1/Rev.1. Retrieved from: http://wto.org/english/thewto_e/minist_e/mc9_e/balipackage_e.htm\#baliministerialdeclaration. 


\section{APPENDICES}

Table-A1. List of former French colonies in SSA.

\begin{tabular}{c|c|c|c|c}
\hline Benin & Burkina Faso & Ivory Coast & Djibouti & Gabon \\
\hline Guinea & Madagascar & Mauritania & Mali & Niger \\
\hline CAR & DRC & Senegal & Chad & Togo \\
\hline
\end{tabular}

Table-A2. List of former British colonies in SSA.

\begin{tabular}{c|c|c|c|c}
\hline South Africa & Botswana & Gambia & Ghana & Kenya \\
\hline Lesotho & Malawi & Nigeria & Seychelles & Sierra Leone \\
\hline Swaziland & Tanzania & Uganda & Zambia & Zimbabwe \\
\hline
\end{tabular}

Table-A3. Abbreviation of Variables.

\begin{tabular}{l|l|l}
\hline Variables & Variable definitions (measurement) & Sources \\
\hline HDI & level of development of the world countries & World perspective \\
\hline WTS & Authors Calculation & Squalli and Wilson (2011) \\
\hline INF & Price consomption index & World Perspective \\
\hline FDI & Foreign Direct Investment, net inflows (\% GDP) & World Perspective \\
\hline EXDI & Level of diversification of a economy through exports & WTO (UNITAD) \\
\hline OPEN & Total amount of exports and import of goods and services (\% of GDP) & World Bank (WDI) \\
\hline
\end{tabular}

